FACTA UNIVERSITATIS

Series: Physical Education and Sport Vol. 15, N ${ }^{\mathrm{o}} 3,2017$, pp. 437 - 451

https://doi.org/10.22190/FUPES1703437C

Research article

\title{
EFFECTS OF THE FITT PROGRAM ON PHYSICAL ACTIVITY AND HEALTH-RELATED FITNESS IN PRIMARY SCHOOL AGE CHILDREN
}

\author{
UDC 796.015-053.5
}

\author{
Dragan Cvejić $\mathfrak{1}^{1}$, Sergej Ostojić \\ ${ }^{1}$ University of Novi Sad, Faculty of Education, Sombor, Serbia \\ ${ }^{2}$ University of Novi Sad, Faculty of Sport and Physical Education, Novi Sad, Serbia
}

\begin{abstract}
Evaluation of the effects of an eight-week innovative FITT program of Physical Education to Physical Activity (PA) and health-related fitness (HRF). In the experimental group (N=92), with FITT guidelines, the students have been "introduced" to the development of the HRF zone. There have been 16 classes for the development of the aerobic fitness and 8 classes for the development of muscular fitness. Flexibility has been developed in the final parts of each class. The control group $(N=86)$ attended traditional classes of the same volume. Before and after the intervention, the HRF components evaluation was performed with the battery of FITNESSGRAM tests and the PA by the pedometer OMRON HJ-320. Both groups showed a significant increase in the maximum consumption of oxygen and the number of depleted shares (PACER laps), with the simultaneous decrease in the PA level. The FITT program significantly contributed to the improvement of aerobic fitness, muscular fitness and partially flexibility. There was no difference between the group in the body composition and the PA level. FITT intervention is a promising school strategy for improving the aerobic and muscular fitness of students.
\end{abstract}

Key words: school intervention, physical education, third-grade students

\section{INTRODUCTION}

There is an increasing number of scientific evidence of the positive effects of PA (Strong et al., 2005; Physical Activity Guidelines Advisory Committee, 2008; Kamijo et al., 2011; Centers for Disease Control and Prevention, 2010; Fedewa \& Ahn, 2012) and the interconnected HRF (Smith et al., 2014; Faigenbaum et al., 2009; Ruiz et al., 2009; LaVigne, Hoza, Smith, Shoulberg, \& Bukowski, 2016; Coe, Pivarnik, Womack, Reeves,

Received Septmber 18, 2017 / Accepted January 15, 2018

Corresponding author: Dragan Cvejić

University of Novi Sad, Faculty of Education, Podgorička 4, 25101 Sombor, Serbia

Phone: +38125 412-030• E-mail: dragan.cvejic@ pef.uns.ac.rs 
\& Malina, 2012; Sardinha et al., 2016; Scudder et al., 2014) on the physical and mental health of children and youths.

Contrary to the many benefits, the physical activity of children of all ages is constantly decreasing (Bornstein, Beets, Byun, \& McIver, 2011; Konstabel et al., 2014), and consequently the HRF (Ostojić \& Stojanović, 2010; Ostojić, O'Neil, Calleja, Terrados, \& Stojanović, 2010; Ostojić, Stojanović., Stojanović, \&, Marić, 2010; Ostojić, Stojanović, Stojanović, Marić, \& Njaradi, 2011; Đordjić et al., 2016).

Considering the current situation, it is necessary to increase the volume (frequency, intensity or duration) of physical activities in all age groups (Cvejić \& Buišić, 2012) and especially those types of activities that will contribute to the development of HRF components (aerobic fitness, muscular fitness, flexibility and body composition).

There are numerous programs in the world for increasing PA and improvement of the HRF of children and adolescents: school-based, family-based, Programs of the local or wider community, on-line programs, comprehensive programs. [TAKE 10 (Goh, Hannon, Webster, Podlog, \& Newton, 2016); Sports, Play and Active Recreation for Kids - SPARK (McKenzie, Sallis, \& Rosengard, 2009); Healthy Hearts 4 Kids (Palmer, Graham, \& Eloise, 2005); Middle School Physical Activity and Nutrition M-SPAN (McKenzie et al., 2004); Health Optimizing Physical Education - HOPE (Sallis et al., 2012); Born to Move - BTM (Fairclough et al., 2016); Knowledge in Action - KIA (Hodges, Kulinna, Van Der Mars, \& Lee, 2016); Comprehensive school PA program - CSPAP (NASPE, 2008); Kinder-Sportstudie - KISS (Zahner et al., 2006); and many others].

According to the recommendations of numerous studies and leading organizations (Burgeson, Wechsler, Brener, Young, \& Spain, 2001; Council of Europe, Committee of Ministers, 2004; Pate et al., 2006; WHO, 2004), schools should take on the role of leaders in increasing PA and improving students' HRF. School interventions contribute to an increase in the duration of physical activity of 5 to 45 minutes per day, reduce the time spent watching television from 5 to 60 minutes per day and increase the maximum oxygen consumption from 1.6 to $3.7 \mathrm{ml} / \mathrm{kg} / \mathrm{min}$ (Dobbins, Husson, DeCorby, \& LaRocca, 2013). While some school programs include additional physical education (PE) classes or additional activities (active breaks, activities before or after classes), others are based on curriculum changes. Increasing frequency and duration is not always possible, given the competitive requirements of the curriculum, so it is important to stimulate physical activity within classes and breaks, and to develop strategies for more efficient use of PE classes.

The aim of the research is to evaluate the effects of the foremost innovative FITT Physical Education Program on PA and HRF of primary school age children.

\section{METHODS}

The research is a quasi-experimental, of a longitudinal type and was conducted from September to December 2015. It was used a pretest - posttest research project with randomized groups. Of five elementary schools in Sombor, by random selection, four classes from three schools were assigned to the experimental (EXP) group, and four into the control (CON) group. In the EXP group, through the FITT Guidelines, students have been "introduced" to the development zone of health-related components. After eight 
weeks, 16 classes were done for the development of aerobic fitness and 8 classes for the development of muscular fitness (three 45 minute/classes/week). Flexibility has been developed in the final part of each class. The experimental program, based on the preparation conceived by the author, was realized by two previously instructed students of the Faculty of Education. In the CON group, teachers, based on personal preparations, realized a regularly planned curriculum, with traditional teaching strategies.

\section{Participants}

The research approval was obtained from the University of Novi Sad and the Faculty of Sport and Physical Education in Novi Sad, Republic of Serbia. Before conducting the research, written consent was received from the director of all three schools and the parents of children included in the research.

The sample has the characteristics of an appropriate and random group (cluster) sample. Out of the 182 third-graders included in the survey, 178 students (aged $9.02 \pm$ 0.33 years old at the initial testing) participated in the interpretation of the results, of which 92 in EXP and 86 in CON group (two excluded due to developmental disturbances, one changed schools and one got sick).

\section{Measuring instruments and organization of measurements}

Health-related fitness was assessed using the FITNESGRAM battery test (The Cooper Institute, 2010). The aerobic fitness was assessed using the Progressive Aerobic Cardiovascular Endurance Run test (PACER laps). Based on this test, using the regression equation (Mahar, Guerieri, Hanna, \& Kemble, 2011) the maximum oxygen consumption (VO2max) was calculated. Muscular form was assessed by the tests: curl-up and $90^{\circ}$ push-up. Flexibility was assessed by the tests: back-saver sit and reach - left leg stretched (LLS) and back-saver sit and reach - right leg stretched (RLS) and shoulder stretch left hand up (LHU) and shoulder stretch - right hand up (RHU). Body composition was assessed by measuring skin folds on triceps and calf by the Slim Guide Skin fold caliper, as well as calculating the body mass index (BMI). To calculate the body fat percentage (BFP) based on the measuring skin folds on triceps and calf it was used the formula developed by Slaughter and Lohman (Slaughter et al., 1988).

Two weeks before the start of the research study, there was a lecture on the correctness of the performance of the tests for the evaluation of HRF components, which is consistent with the FITNESSGRAM Guidelines. Before and after the experimental program, prepared examiners "blinded" by the group's affiliation, performed the testing. The examiners had an identical task on both measurements.

PA was evaluated by a pedometer OMRON HJ-320 which has a seven-day memory with automatic recording at 00:00 h. In previous studies (Park, Lee, Ku, \& Tanaka, 2014), it showed a solid accuracy of measurement at different movement speeds (from $54 \mathrm{~m} / \mathrm{min}$ to $161 \mathrm{~m} / \mathrm{min}$ ) and at different places of wear (in the pocket, on the chest, on the belt, on the hand or in the purse). One week before the start of the experimental program, the students carried a pedometer based on which initial data were obtained on the number of steps taken. The final measurement was done in the last week of the program.

All pedometer results below 1000 daily steps and above 30000 daily steps were erased and treated as missing data (Rowe, Mahar, Raedeke, \& Lore, 2004). The 
replacement procedure for missing data was carried out according to the procedure of Kang, Zhu, Tudor-Locke, \& Ainsworth (2003). After the data was sorted, 18 data on the initial measurement and 14 on the final one were missing. These data were further replaced with the average value of the group on the day the data was missing. The final result of the number of steps taken has been calculated for each respondent as the average number of steps during the day (average daily steps).

\section{FITT program}

The FITT program is a comprehensive program for the more efficient use of existing PE classes fund in the lower grades of elementary school. It was created by the synthesis of scientific information from effective school interventions. It focuses on improving the components of the health-related fitness, which is possible only if it is exercised in their development zone. It rests on a scientific concept which has not found application in the traditional teaching of physical education. This concept includes the basic principles of training (overload, progression, specificity, continuity and individuality), the application of which is facilitated by FITT guidelines (FITT is an acronym frequency, intensity, time, type) (Ayers \& Sariscsany, 2011). In the FITT program, primarily teaching contents, methods, forms and other teaching instrument of work are used so that the planned physical activity or exercise by frequency, intensity, duration and type leads to the improvement of aerobic fitness, muscular fitness and flexibility, and indirectly to the improvement of body composition (see Table 1).

Table 1

\begin{tabular}{|c|c|c|c|c|}
\hline HRF & Frequency & Intensity & Duration & Type \\
\hline \multirow{2}{*}{$\begin{array}{l}\text { Aerobic } \\
\text { fitness }\end{array}$} & \multirow{2}{*}{2 clases/week } & a) moderate & $\begin{array}{l}\text { Continuous activity } \\
\text { up to } 5 \text { minutes }\end{array}$ & $\begin{array}{l}\text { Activities that engage } \\
\text { large muscle groups } \\
\text { (running, fast walking, } \\
\text { skipping rope ...) } \\
\end{array}$ \\
\hline & & $\begin{array}{l}\text { b) high with } \\
\text { periods of rest }\end{array}$ & $\begin{array}{l}\text { Intensive activity for } 3-4 \\
\text { minutes with shorter rest } \\
\text { periods }\end{array}$ & $\begin{array}{l}\text { Activities that engage } \\
\text { large muscle groups } \\
\text { (polygons or } \\
\text { elementary games) }\end{array}$ \\
\hline $\begin{array}{l}\text { Muscular } \\
\text { fitness } \\
\text { (strength, } \\
\text { endurance, } \\
\text { power) } \\
\end{array}$ & 1 classc/week & Very light loads & $\begin{array}{l}1 \text { to } 2 \text { series; } 8-10 \text { exercises; } \\
\text { from } 6 \text { to } 15 \text { reps ( } 36 \text { to } 90 \\
\text { seconds); Total duration is } \\
20-28 \text { minutes }\end{array}$ & $\begin{array}{c}\text { Exercises to } \\
\text { strengthen larger } \\
\text { muscle groups; One } \\
\text { exercise per muscle or } \\
\text { muscle group }\end{array}$ \\
\hline Flexibility & $\begin{array}{l}3 \text { clasess/ week } \\
\text { (final part of } \\
\text { the class) }\end{array}$ & $\begin{array}{l}\text { Light (static) } \\
\text { stretching of the } \\
\text { muscles until the } \\
\text { first appearance of } \\
\text { pain and discomfort }\end{array}$ & $\begin{array}{l}2 \text { stretches for the same muscle } \\
\text { group; keep the segment } \\
\text { stretched for } 10-20 \text { seconds; } \\
\text { pause for } 10 \text { seconds; } 5 \\
\text { exercises per class; }\end{array}$ & $\begin{array}{l}\text { All muscle groups } \\
\text { (depending on class } \\
\text { activity) }\end{array}$ \\
\hline
\end{tabular}

The basic principles of training and FITT guidelines are well described in the Physical Education for Lifelong Fitness: The Physical Best Teacher's Guide (Ayers \& Sariscsany, 2011) and Fitness for Life (Corbin \& Le Masurier, 2014). The basic principles of training are the foundation for all physical exercise programs, and the same should also be applied for PE classes. 
At the same time, when creating the FITT program, it was taken into account that it should contribute to the students':

- development of knowledge (cognitive domains) about health-related fitness components and ways of its improvement, proper nutrition, importance of fitness for health, risks of inactivity, recommendations regarding physical activities and sedentary time;

- acquisition of knowledge and skills (a psychomotor domain) through which students will be able to develop components of the HRF;

- developing positive attitudes (affective domains) about physical activity and physical exercise.

In order to plan time in the primary school age children in accordance with the basic principles of training and FITT guidelines, 5 methodological approaches from 11 described in Mosston \& Ashworth (2008) were used: direct, practical teaching, work in pairs / group, inclusion and learning through discovery. The above-mentioned methodical approaches require more time to prepare the class, but they enable individualization, everybody's involvement in the exercise process, regardless of their previous abilities, intensification of activity in class and increased active exercise time.

\section{Statistical Analysis}

The data obtained by testing were entered into the statistical package of SPSS $® 20.0$ (Statistical Package of Social Sciences - for Windows, Inc., Chicago, IL). As part of the preliminary analysis, the basic descriptive statistics were calculated (mean, standard deviation) and normal distribution were tested using the Kolmogorov-Smirnov test. Data whose distribution deviated from the normal have been transformed (only on initial measurement for variables: BFP, Curl-up, LLS and RLS). Variable $90^{\circ}$ push-up had a distribution on both measurements that deviated from normal and could not be transformed. With the variable BFP, the extreme value at ID55 was replaced before the analysis with the first lower value of the complete sample (40.68 at the initial measurement and 39.56 at the final measurement). The quantitative differences at the initial measuring between the EXP and CON group were determined for the categorical data by the Chi-square test for independence testing, for regularly distributed and transformed data by independent samples t-test, and for data whose distribution deviated from normal with Mann-Whitney U Test.

The effect of intervention on the aerobic fitness (PACER laps and $\mathrm{VO}_{2 \max }$ ) and the level of physical activity (average daily step) was established by the 2 x 2 ANOVA (group $\mathrm{x}$ time). In the remaining variables, the quantitative differences during the final measurement are established as during the initial one (depending on the type and distribution of data).

\section{RESULTS}

\section{Initial comparisons}

By examining the differences between the EXP and CON group at the initial measurement (see Table 2), it was found that none of the 9 observed variables had statistically significant differences at the assessment level $p<.05$. 
Chi-squared test with Yates continuity correction did not show a statistically significant difference between groups not even in the variable LHU, c2 $(1, \mathrm{n}=178)=.03$, $p=.86$, phi $=.03$, neither in the variable RHU, c2 $(1, \mathrm{n}=178)=.41, p=.52$, phi $=-.07$. U EXP group 30 (32.6\%) participants', and in CON group $26(30,2 \%)$ the participants' failed to fulfill the task that represents the variable LHU. The task which represents the variable RHU failed to fulfill 8 (8.7\%) participants' in the EXP group and $11(12,8 \%)$ in the CON group.

Table 2 Basic descriptive statistics and group differences on initial and final measurement

\begin{tabular}{|c|c|c|c|c|c|}
\hline \multirow[b]{2}{*}{ Outcomes } & \multicolumn{2}{|c|}{ EXP group $(N=92)$} & \multicolumn{2}{|c|}{$\mathrm{CON}$ group $(\mathrm{N}=86)$} & Pre Post \\
\hline & Pre & Post & Pre & Post & $p \quad P$ \\
\hline Age (years) & $9.02 \pm .33$ & & $9.01 \pm .27$ & & \\
\hline Body mass (kg) & $33 \pm 7.5$ & $33.73 \pm 7.68$ & $34.5 \pm 8.2$ & $35.36 \pm 8.55$ & \\
\hline Body height $(\mathrm{cm})$ & $137.1 \pm 6.71$ & $137.89 \pm 6.84$ & $138.26 \pm 5.56$ & $139.08 \pm 5.76$ & \\
\hline Body mass index $(\mathrm{kg} / \mathrm{m} 2)$ & $17.45 \pm 3.15$ & $17.61 \pm 3.1$ & $17.90 \pm 3.27$ & $18.14 \pm 3.45$ & .34 .29 \\
\hline Body fat percentage & $18.52 \pm 6.92$ & $18.48 \pm 6.95$ & $19.83 \pm 7.47$ & $19.79 \pm 7.55$ & .20 .23 \\
\hline aCurl-up (repetition) & $9.45 \pm 8.15$ & $18.49 \pm 10.74$ & $10.97 \pm 7.49$ & $12.36 \pm 8.65$ & 12.000 \\
\hline $90^{\circ}$ push-up (repetition) & $5.60 \pm 5.69$ & $8.38 \pm 7.34$ & $4.58 \pm 5.85$ & $4.43 \pm 5.66$ & .09 .000 \\
\hline $\begin{array}{l}\text { Back-saver sit and reach - left leg } \\
\text { stretched }(\mathrm{cm})\end{array}$ & $24.74 \pm 4.82$ & $25.07 \pm 4.7$ & $25.87 \pm 5.01$ & $24.58 \pm 5.22$ & .09 .52 \\
\hline $\begin{array}{l}\text { Back-saver sit and reach - right leg } \\
\text { stretched }(\mathrm{cm})\end{array}$ & $24.60 \pm 4.89$ & $24.66 \pm 4.69$ & $25.55 \pm 5.21$ & $24.44 \pm 5.19$ & .11 .77 \\
\hline PACER (laps) & $17.53 \pm 9.12$ & $21.96 \pm 10.26$ & $15.69 \pm 7.01$ & $17.16 \pm 8.06$ & .13 \\
\hline $\mathrm{VO}_{2} \max (\mathrm{ml} / \mathrm{kg} / \mathrm{min})$ & $39.96 \pm 4.86$ & $41.45 \pm 5.09$ & $39.22 \pm 4.65$ & $39.61 \pm 4.87$ & .31 \\
\hline Average daily steps & $9900 \pm 3526$ & $8836 \pm 2432$ & $10488 \pm 3433$ & $8425 \pm 2781$ & .26 \\
\hline
\end{tabular}

Note: ${ }^{a}$ group comparison performed by Man-Whitney U test; Other comparison performed by indenpendent sample t-test;

\section{Final comparisons}

A significant interaction occurred in $\mathrm{VO}_{2}$ max between the type of intervention and time, Wilks's lambda $=.92, F_{(1,176)}=15.8, p=.00$, partially $\eta^{2}=0,8$. Significant separate influence of time was established, Wilks's lambda $=.79, F_{(1,176)}=46.25, p=.00$, partially $\eta 2=.20$, wherein in both groups there was an increase in the $\mathrm{VO}_{2}$ max. The individual impact of the two interventions was not significant, $F_{(1,176)}=3.2, p=.076$, partially $\eta^{2}=$ .02 , which means that both interventions contributed to the improvement of $\mathrm{VO}_{2} \mathrm{max}$.

A significant interaction between the type of intervention and time also occurred in the number of run distances (PACER laps), Wilks's lambda $=.92, F_{(1,176)}=15.3, p=.00$; partially $\eta^{2}=.08$. Significant separate influence of time was established, Wilks's lambda $=.74, F_{(1,176)}=61.35, p=.00$, partially $\eta 2=.26$, with both groups increasing in the number of run distances. It is important to note that the participants of the FITT program ran significantly more laps, $F_{(1,176)}=7.01 ; p=.009$, partially $\eta^{2}=0,04$.

Statistically significant $(p<.001)$ progress of the EXP group is also observed in the muscular fitness in both variables (Curl-up: $t(178)=4.18, p=.000$, mean difference $=$ $6.13,95 \% \mathrm{CI}$ : from 3.23 to $9.02, \eta 2=.09$; and $90^{\circ}$ push-up: EXP group $\mathrm{Md}=7$ vs. KON group $\mathrm{Md}=2, \mathrm{U}=2439.5, z=-4.44, p=.000, \mathrm{r}=.33$ ) (see Table 2).

There were no statistically significant differences between groups in body composition (BMI, BFP) and flexibility (LLS, RLS). 
At the final measurements in the EXP group of 11 participants or $12 \%$, and in CON group 24 participants or $27.9 \%$ failed to fulfill the task representing the variable LHU. A much smaller number of participants, 3 or $3.3 \%$ in the EXP and 10 or $11.6 \%$ in the CON group failed to fulfill the task that represents variable RHU. Chi-square independence test (with Yates correction of continuity) showed statistically significant difference in favor of EXP group in variables LHU, c2 $(1, \mathrm{n}=178)=6.18, p=.01$, fi $=-0.20$, while in the variable RHU, was on the very threshold of significance $\mathrm{c}^{2}(1, \mathrm{n}=178)=3.44, p=.06$, fi $=-0,16$.

At the PA level, significant interaction occurred between the type of intervention and time, Wilks's lambda $=0.97, F_{(1,176)}=4.91, p=.03$, partially $\eta^{2}=.03$. PA level, expressed by the average number of daily steps between two measurements in both groups decreased, Wilks's lambda $=.78, F_{(1,176)}=48.16, p=.00, \eta^{2}=.22$. The individual impact of the two interventions was not significant, $F_{(1,176)}=.05, p=.82$, partially $\eta^{2}=.00$, which means that neither of the programs was effective enough.

Due to the previously established statistically significant differences between boys and girls aged 9, in flexibility, body composition, aerobic capacity and PA, the calculation of average values on initial and final measurement by gender for the whole sample was performed, as well as the determination of the significance of the difference between the t-test series.

By looking at the data presented in Table 3, we can conclude that there are statistically significant differences in boys' and girls' differences in flexibility, aerobic ability, level of physical activity and body composition (BFP). The body mass index "concealed" the real differences in the body composition that at this age exist between boys and girls.

Table 3 Differences by gender on initial and final measurment

\begin{tabular}{llcccccc}
\hline Outcomes & & \multicolumn{3}{c}{ Whole sample } & & & \\
\cline { 3 - 4 } & & Female N=86 & Male N=92 & & $p$ & \multicolumn{1}{c}{$t$} & $\eta^{2}$ \\
\hline Body mass index $\left(\mathrm{kg} / \mathrm{m}^{2}\right)$ & Pre & $17.87 \pm 3.68$ & $17.47 \pm 2.73$ & .41 & 0.41 & 0,00 \\
& Post & $17.98 \pm 3.71$ & $17.76 \pm 2.82$ & .66 & 0.66 & 0,00 \\
Body fat percentage & Pre & $20.82 \pm 7.11$ & $17.59 \pm 6.98$ & .003 & 3.05 & 0,05 \\
& Post & $20.61 \pm 7.12$ & $17.71 \pm 7.13$ & .007 & 2.72 & 0,04 \\
Back-saver sit and reach - left & Pre & $26.47 \pm 4.67$ & $24.18 \pm 4.93$ & .002 & 3.16 & 0,05 \\
leg stretched (cm) & Post & $26.37 \pm 4.37$ & $23.39 \pm 5.06$ & .000 & 4.19 & 0,09 \\
Back-saver sit and reach - & Pre & $26.38 \pm 4.76$ & $23.82 \pm 5.02$ & .001 & 3.49 & 0,06 \\
right leg stretched (cm) & Post & $25.83 \pm 4.57$ & $23.37 \pm 4.96$ & .001 & 3.42 & 0,06 \\
V0 ${ }_{2}$ max (ml/kg/min) & Pre & $36.91 \pm 3.75$ & $42.11 \pm 4.21$ & .000 & -8.68 & 0,30 \\
& Post & $37.75 \pm 3.87$ & $43.19 \pm 4.61$ & .000 & -8.49 & 0,29 \\
PACER laps & Pre & $14.06 \pm 5.65$ & $19.05 \pm 9.46$ & .000 & -4.33 & 0,10 \\
& Post & $16.34 \pm 5.97$ & $22.73 \pm 11.13$ & .000 & -4.82 & 0,12 \\
Average daily steps & Pre & $9298 \pm 2555$ & $11012 \pm 4009$ & .001 & -3.42 & 0,06 \\
& Post & $7920 \pm 2077$ & $9308 \pm 2872$ & .000 & -3.71 & 0,07 \\
\hline
\end{tabular}




\section{DISCUSSION}

\section{Aerobic fitness}

Both traditional and innovative PE classes contribute to the development of aerobic fitness, as both groups have achieved significant statistical progress in $\mathrm{VO}_{2} \mathrm{max}$ and in the number of distances ran (PACER laps). Although it does not go hand in hand with this research, it must be acknowledged that one of the reasons for the increase lies in the fact that during the long summer break children are insufficiently active, which causes a fall in HRF. With the start of school, PA is increased, and consequently also the aerobic fitness. Progress in the CON group is not surprising due to the fact that at the younger school age, during each PE class (three classes/week), competitor or play-like activities are being played (chase, dodgeball...) last for about 10 minutes, which contributes to the development of aerobic fitness.

However, a statistically significant increase in the number of distances ran (PACER laps) in the EXP group indicates that the FITT program is more effective than the traditional one.

Estimated $\mathrm{VO}_{2}$ max of the students involved in this study, regardless of the time of measurement, is lower than in a similar study by Gallotta et al. (2017) and significantly lower than the standards defined for normally nourished European children of the same age shown in the work of De Miguel-Etayo et al. (2014). In relation to the normative values, on the overall sample, the $\mathrm{VO}_{2}$ max student in our study at initial and final testing is below the $1^{\text {st }}$ percentile for girls, while in the boys between $10^{\text {th }}$ and $25^{\text {th }}$ percentile. Our research also includes obese children, which can "bend" the actual picture when compared. Still, children from European countries appear to have a better aerobic form.

It is alarming that the average results of VO2max students in this survey are just slightly above the international threshold for identifying children with poor health by Ruiz et al. (2016) from $35 \mathrm{~mL} / \mathrm{kg} / \mathrm{min}$ for girls and $42 \mathrm{~mL} / \mathrm{kg} / \mathrm{min}$ for boys. On the initial measurement $21(24.4 \%)$ girls and even $55(59.8 \%)$ boys had values below this standard.

Statistically significant progress in the EXP group at the final measurement relative to the initial, with an average increase in the maximum oxygen consumption of 1.49 $\mathrm{ml} / \mathrm{kg} / \mathrm{min}$, is in line with previous studies in this range from 1.6 to $3.7 \mathrm{ml} / \mathrm{kg} / \mathrm{min}$, was shown in the review of Dobbins et al. (2013). In this review, the greatest average improvement in the maximum oxygen consumption of $3.7 \mathrm{ml} / \mathrm{kg} / \mathrm{min}$ was determined by objective measurements on the treadmill with spirometer in a study involving 182 students of an average age of 11 (Walther et al., 2009). The students in the Experimental group participated in everyday PE classes, in contrast to the Control group who had three classes a week. The intervention lasted for one year, and changes were observed in the body composition (BMI and BFP based on bioelectrical impedance), and changes in biochemical markers (total cholesterol, triglycerides ...). The effect of intervention was not registered on changes in BMI and changes in BFP.

In order to achieve and maintain aerobic fitness, a constant, convenient and specific dosage of the duration and intensity of aerobic activities is required (Lai et al., 2014) with emphasis on the total volume (Weineck, 2007). Although successful interventions to improve the aerobic fitness of children consisted of daily sessions of a duration of 45 minutes (Kriemler et al., 2011), the results of this study show that it is possible to make progress with two classes in the weekly cycle. In order to increase the total volume of activities in a two-class weekly cycle, it was necessary to increase the intensity of work 
and the active time of exercise. Knowing and using the FITT guidelines, the application of the basic principles of training and "new" methodical approaches in our school practice, have allowed an optimal dosage for the development of an aerobic fitness at all classes.

\section{Muscular fitness}

The FITT program contributed to the development of muscular fitness. Progress of the EXP group is in line with the research (Faigenbaum et al., 2013; Faigenbaum et al., 2011; Jones et al., 2011) in which physical exercises are planned for muscular fitness development. Comparing the average values on the initial measurement in the variables Curl-up and $90^{\circ}$ push up, with results (Fox, 2014), hull lift AS $=29.67$ and $\mathrm{AS}=16.11$, but also with other studies (Gallotta et al., 2016; Kabiri, Mitchell, Brewer, \& Ortiz, 2017; Reynolds et al., 2010), we can conclude that the muscular fitness of our students is bad. Obviously, in our schools, the work done is insufficient to improve the muscular fitness. In order to make progress in the muscular fitness, it is necessary to specifically plan activities and exercises for their development, at least 2 to 3 times in a weekly cycle (Behringer, vom Heede, Yue, \& Mester, 2010; Faigenbaum et al., 2009). Based on this research, it seems that even one class is sufficient to show the effect. As with aerobic fitness, to optimize the muscular fitness, optimal dosing is crucial, which has been achieved by the FITT program.

\section{Flexibility}

The flexibility of children of a younger school age is usually very high, with girls being more flexible. This was also shown by the results of the tests at initial and final measurements, where all average values for both Back-saver sit and reach for boys are over $23 \mathrm{~cm}$, and for girls over $25 \mathrm{~cm}$. Values are more than the minimum required by FITNESSGRAM health standards (for boys over $20.3 \mathrm{~cm}$ and girls over $22.9 \mathrm{~cm}$ ). The results are based on age and gender according to the research presented in the United States (Fox, 2014) and the European Union (De Miguel-Etayo et al., 2014). Comparing the results of our research with standards (De Miguel-Etayo et al., 2014), we conclude that all the results (both for boys and girls) are high in the range from 75 to 90 percent.

The results of the final measurement showed statistically significant progress in the EXP group relative to the CON group only in the variable LHU.

The FITT program partly contributed to the development of flexibility, which was also found in other similar studies (e.g. Jarani et al., 2016). It is possible that initially a high degree of flexibility was established among students of this age, i.e. threshold reached, is the limiting factor in its development. Another possible reason is insufficient scope of activities. It is recommended that, apart from the stretching activities needed in the preparatory (warm up) and final (cooling down) part of the class, in the weekly cycle 3 times/week, some independent activities are organise that contribute to the development of flexibility. In this study, as well as the research of Jarani et al. (2016), such activities were not separately organized. 


\section{Body composition}

Regardless of the progress in $\mathrm{VO}_{2}$ max, there was no change in the BMI and BFP, which is similar to that of Walter et al. (2009). This result is consistent with the results of meta-analyses that concluded that interventions carried out in the school environment have little impact on BMI (Guerra, Nobre, Silveira, \& Aguiar Carrazedo Taddeial, 2013; Harris, Kuramoto, Schulzer, \& Retallack, 2009), but also on other measurements of the body composition of children (Harris et al., 2009). As a possible reason for failure of the interventions Harris et al. (2009) emphasize the insufficient level (duration, intensity, frequency) of physical activities necessary to make the change. Another possibility is that PA has a lesser effect on body composition than dietary factors. It is certainly a limiting factor that in some studies, included in the meta-analysis, maybe there has been a change in BFP (not a research outcome), but this does not apply to BMI. The BMI often conceals real differences in body composition, as observed in this study when comparing differences between boys and girls. Contrary to these results, interventions carried out in the school environment (Carrel et al., 2005; Kain, Uauy, Vio, Cerda, \& Leyton, 2004; Kriemler et al., 2010) have a positive effect on the body composition. Basically these are comprehensive interventions from a minimum of six months. Some interventions include additional classes of PE (Kriemler et al., 2010). It is recommended that interventions that are implemented in the school environment and that are focused on changes in the body composition last for a minimum of one year (Guerra et al., 2013), and that they are comprehensive and involve all school staff, parents and the local community.

\section{PA level}

Between two measurements, PA dropped in both groups, which could have been expected, having in mind that the initial measurement was conducted from September 14 to 21 , and finally from November 23 to 30 , when there is very different daytime. Seasonal variations in PA measurement have already been explained (Beighle, Alderman, Morgan \& Masurier, 2008; Gorely et al., 2011). Weather conditions created an additional problem. At the moment of initial measurement, Sombor was hit by a thermal wave with maximum temperatures of up to $36.5^{\circ} \mathrm{C}$ and without precipitation, and at the moment of final measurement, a cooler wave with rain (Republic Hydro-meteorological Service of Serbia, 2015). Bad weather conditions during the final measurement restricted children from playing outside.

Although not statistically significant, the decline in the level of activity in the CON group (the average difference between the two measurements is 2063 steps) is more drastic than in the EXP group (the average difference is 1064 steps).

According to the average number of steps accumulated by girls (9 298 steps) and boys (11 012 steps) at the initial measurement (when there were ideal conditions for physical activity and when all sports sections started after a summer break), we can conclude that they do not comply with the recommendations (Tudor-Locke et al., 2011) of the minimum required daily steps (girls 11000 to 12000 steps a day, and boys from 13000 to 15 000). Although this data cannot be generalized to the entire population of children in Serbia, due to the sampling method, we can assume that the situation is similar.

Based on the results obtained from the pedometers, we could conclude that our intervention aimed at increasing the level of PA in children has little impact, as in the 
meta-analysis of Metcalf, Henley, \& Wilkin (2012). Comparability is not complete, given the fact that in the mentioned meta-analysis, as an inclusion criterion, an accelerometer was used which, unlike the pedometer, has the ability to quantify the duration, frequency and intensity of individual activities. However, by analyzing the results of the EXP group in the HRF components, we are seeing a new situation. Although the level of PA significantly decreased between two measurements, aerobic and muscular fitness significantly improved. It is impossible to make progress in shape without increasing at least one of the factors (frequency, time, duration or intensity of physical activity). The pedometer does not have the ability to quantify the duration, frequency and intensity of the activity, which is not the only disadvantage. The end result is also affected by seasonal variations, but also by meteorological conditions at the moment of recording. Based on the above facts, we can recommend that the effect of interventions on the increase of children PA should be better observed through changes in the aerobic fitness rather than on the PA measurement by pedometers. In any case, due to the comparability of the results, the complete circumstances in which the testing was performed (air temperature, precipitation, daytime, etc.) should also be shown.

\section{CONCLUSION}

On the basis of valid and reliable data collection techniques, we can conclude that PA is low among third-grade primary school students in Sombor and that it is not in accordance with valid recommendations. And HRF is at an unsatisfactory level. The great progress of the students who took part in the eight-week innovative FITT program is evident in the majority of observed variables, and exceptional progress has been achieved in aerobic and muscular fitness. The key element which led to improvement in the EXP group is probably the correct and optimal choice of the type, duration, intensity and frequency of physical exercise and physical activity in all of the PE classes. Individually tailored physical exercise is the most important factor that maintains and improves the Health-related fitness. By applying methodological approaches (Mosston \& Ashworth, 2008), it is possible to develop an individually tailored program in teaching physical education for primary school age children. PE is the most important means of a society for the preservation and strengthening of children's health. In the following period, it is necessary to insist on increasing the number of PE classes to one class a day, but also on starting the school projects that contribute to the increase of students' PA and HRF (optional class of PE, extra class in extended stay, school sections for all children, organized physical activities on big breaks...). In the structure of PE, it is necessary to make big changes. Classes should be planned in accordance with scientific achievements in this field - basic principles of training and FITT guidelines and focused on the development of HRF components. 


\section{REFERENCES}

Ayers, S. F., \& Sariscsany, M. J. (2011). Physical education for lifelong fitness: the physical best teacher's guide. Human Kinetics.

Behringer, M., vom Heede, A., Yue, Z., \& Mester, J. (2010). Effects of resistance training in children and adolescents: a meta-analysis. Pediatrics, 126, 119-210.

Beighle, A., Alderman, B., Morgan, C. F., \& Masurier, G. L. (2008). Seasonality in children's pedometer-measured physical activity levels. Research quarterly for exercise and sport, 79(2), 256-260.

Bornstein, D.B., Beets, M.W., Byun, W., \& McIver, K. (2011). Accelerometer-derived physical activity levels of preschoolers: a meta-analysis. Journal of Science and Medicine in Sport, 14(6), 504-511.

Burgeson, C.R., Wechsler, H., Brener, N.D., Young, J.C., \& Spain, C.G. (2001). Physical education and activity: Results from the school health policies and programs study 2000. Journal of School Health, 71(7), 279-293.

Carrel, A. L., Clark, R. R., Peterson, S. E., Nemeth, B. A., Sullivan, J., \& Allen, D. B. (2005). Improvement of fitness, body composition, and insulin sensitivity in over- weight children in a school-based exercise program: a randomized, controlled study. Archives of Pediatrics \& Adolescent Medicine, 159(10), 963-968.

Centers for Disease Control and Prevention. (2010). The association between school-based physical activity, including physical education, and academic performance. Atlanta, GA: U.S. Department of Health and Human Services.

Coe, D. P., Pivarnik, J. M., Womack, C. J., Reeves, M. J., \& Malina, R. M. (2012). Health-related fitness and academic achievement in middle school students. The Journal of Sports Medicine and Physical Fitness, 52(6), 654-660.

Corbin, C. B., \& Le Masurier, G. (2014). Fitnessfor life (6.ed.). Human Kinetics.

Council of Europe, Committee of Ministers. (2004). Recommendation Rec(2003)6 of the Committee of Ministers to member states on improving physical education and sport for children and young people in all European countries. Strasbourg: Author.

Cvejić, D., \& Buišić, S. (2012). Integrisanje nastave u cilju povećanja fizičke aktivnosti dece [Integrating teaching in order to increase students' physical activities]. Nastava $i$ vaspitanje, 16(4), 754-765.

De Miguel-Etayo, P., Gracia-Marco, L., Ortega, F. B., Intemann, T., Foraita, R., Lissner, L., et al. (2014). Physical fitness reference standards in European children: the IDEFICS study. International Journal of Obesity, 38, 57-66.

Đorđić, V., Radisavljević, S., Milanović, I., Božić, P., Grbić, M., Jorga, J., \& Ostojić, S. M. (2016). WHO European Childhood Obesity Surveillance Initiative in Serbia: a prevalence of overweight and obesity among 6-9-year-old school children. Journal of Pediatric Endocrinology and Metabolism, 29(9), 1025-1030.

Dobbins, M., Husson, H., DeCorby, K., \& LaRocca, R.L. (2013). School-based physical activity programs for promoting physical activity and fitness in children and adolescents aged 6-18. Cochrane Database of Systematic Reviews, ID CD007651

Faigenbaum, A. D., Farrell, A. C., Fabiano, M., Radler, T. A., Naclerio, F., Ratamess, N. A., et al. (2013). Effects of detraining on fitness performance in 7-year- old children. The Journal of Strength \& Conditioning Research, 27(2), 323-330.

Faigenbaum, A. D., Ferrell, A., Fabiano, M., Radler, T., Naclerio, F., Ratamess, N. A., et al. (2011). Effects of integrative neuromuscular training on fitness performance in children. Pediatric Exercise Science, 23(4), 573.

Faigenbaum, A. D., Kraemer, W. J., Blimkie, C. J., Jeffreys, I., Micheli, L. J., Nitka, M., \& Rowland, T. W. (2009). Youth resistance training: updated position statement paper from the national strength and conditioning association. The Journal of Strength \& Conditioning Research, 23, 60-79.

Fairclough, S. J., McGrane, B., Sanders, G., Taylor, S., Owen, M., \& Curry, W. (2016). A non-equivalent group pilot trial of a school-based physical activity and fitness intervention for 10-11 year old english children: born to move. BMC Public Health, 16(1), 861.

Fedewa, A., \& Ahn, S. (2012). The effects of physical activity and physical fitness on children's achievement and cognitive outcomes: a meta-analysis. Research Quarterly for Exercise and Sport, 82(3), 521-35.

Fox, K. L. (2014). School based intervention for promotion of fitness and academic performance in third grade children. Master's and Doctoral Projects, The University of Toledo, Toledo. http://utdr.utoledo.edu/graduateprojects $/ 10$

Gallotta, M. C., Emerenziani, G. P., Iazzoni, S., Iasevoli, L., Guidetti, L., \& Baldari, C. (2017). Effects of different physical education programmes on children's skill and health-related outcomes: a pilot randomised controlled trial. Journal of Sports Sciences, 35(15), 1547-1555.

Goh, T. L., Hannon, J., Webster, C., Podlog, L., \& Newton, M. (2016). Effects of a TAKE 10!® Classroom-Based Physical Activity Intervention on 3rd to 5th Grades Children's On-task Behavior. Journal of physical activity \& health, 13(7),712-718. 
Gorely, T., Morris, J. G., Musson, H., Brown, S., Nevill, A., \& Nevill, M. E. (2011). Physical activity and body composition outcomes of the GreatFun2Run intervention at 20 month follow-up. International Journal of Behavioral Nutrition and Physical Activity, 8(1), 74.

Guerra, P. H., Nobre, M. R. C., da Silveira, J. A. C., \& de Aguiar Carrazedo Taddei, J. A. (2013). The effect of school-based physical activity interventions on body mass index: a meta-analysis of randomized trials. Clinics, 65(9), 1263-1273.

Harris, K. C., Kuramoto, L. K., Schulzer, M., \& Retallack, J. E. (2009). Effect of school-based physical activity interventions on body mass index in children: a meta-analysis. Canadian Medical Association Journal, 150(7), 719-726.

Hodges, M. G., Kulinna, P. H., Van Der Mars, H., \& Lee, C. (2016). Knowledge in action: Fitness lesson segments that teach health-related fitness in elementary physical education. Journal of Teaching in Physical Education, 35(1), 16-26.

Jarani, J., Grontved, A., Muca, F., Spahi, A., Qefalia, D., Ushtelenca, K., et al. (2016). Effects of two physical education programmes on health-and skill-related physical fitness of Albanian children. Journal of Sports Sciences, 34(1), 35-46.

Jones, R. A., Riethmuller, A., Hesketh, K., Trezise, J., Batterham, M., \& Okely, A. D. (2011). Promoting fundamental movement skill development and physical activity in early childhood settings: a cluster randomized controlled trial. Pediatric Exercise Science, 23(4), 600-615.

Kabiri, L. S., Mitchell, K., Brewer, W., \& Ortiz, A. (2017). Muscular and cardiorespiratory fitness in homeschool versus public school children. Pediatric Exercise Science, 1-19.

Kain, J., Uauy, R., Vio, F., Cerda, R., \& Leyton, B. (2004). School-based obesity preven tion in Chilean primary school children: methodology and evaluation of a controlled study. International Journal of Obesity, 28(4), 483-493.

Kamijo, K., Pontifex, M. B., O'Leary, K. C., Scudder, M. R. Chien-Ting, W., Castelli, D. M., \& Hillman, C. H. (2011). The effects of an afterschool physical activity program on working memory in preadolescent children. Developmental Science, 14, 1046-1058.

Kang, M., Zhu, W., Tudor-Locke, C., \& Ainsworth, B.E. (2003). An experimental determination of the best missing-value recovery method in assessing physical activity using pedometers. Research Quarterly for Exercise and Sport, 74(1), 25-26.

Konstabel, K., Veidebaum, T., Verbestel, V., Moreno, L. A., Bammann, K., Tornaritis, M., et al. (2014). Objectively measured physical activity in European children: the IDEFICS study. International Journal of Obesity, 35, 135-143.

Kriemler, S., Meyer, U., Martin, E., van Sluijs, E. M. F., Andersen, L. B., \& Martin, B. W. (2011). Effect of school-based interventions on physical activity and fitness in children and adolescents: A review of reviews and systematic update. British Journal of Sports Medicine, 45, 923-930.

Kriemler, S., Zahner, L., Schindler, C., Meyer, U., Hartmann, T., Hebestreit, H., et al. (2010). Effect of school based physical activity programme (KISS) on fitness and adiposity in primary schoolchildren: cluster randomised controlled trial. British Medical Journal, 340, 785-792.

Lai, S. K., Costigan, S. A., Morgan, P. J., Lubans, D. R., Stodden, D. F.,Salmon, J., \& Barnett, L. M. (2014). Do school-based interventions focusing on physical activity, fitness, or fundamental movement skill competency produce a sustained impact in these outcomes in children and adolescents? A systematic review of follow-up studies. Sports Medicine, 44, 67-79.

LaVigne, T., Hoza, B., Smith, A. L., Shoulberg, E. K., \& Bukowski, W. (2016). Associations between physical fitness and children's psychological well-be. Journal of Clinical Sport Psychology, 10(1), 32-47.

Mahar, M. T., Guerieri, A. M., Hanna, M. S., \& Kemble, C. D. (2011). Estimation of aerobic fitness from 20-m multistage shuttle run test performance. American Journal of Preventive Medicine, 41(4), 117-123.

McKenzie, T. L., Sallis, J. F., \& Rosengard, P. (2009). Beyond the stucco tower: Design, development, and dissemination of the SPARK physical education programs. Quest, 61, 1-15.

McKenzie, T. L., Sallis, J. F., Prochaska, J. J., Conway, T. L., Marshall, S. J., \& Rosengard, P. (2004). Evaluation of a two-year middle-school physical education intervention: M-SPAN. Medicine \& Science in Sports \& Exercise, 36, 1382-1388.

Metcalf, B., Henley, W., \& Wilkin, T. (2012). Effectiveness of intervention on physical activity of children: Systematic review and meta-analysis of controlled trials with objectively measured outcomes (EarlyBird 54). British Medical Journal, 345, e5888

Mosston, M., \& Ashworth, S. (2008). Teaching physical education (1st online ed.). Buckeystown, MD: Spectrum Institute for Teaching and Learning. 
National Association for Sport and Physical Education-NASPE. (2008). Comprehensive school physical activity programs (Position statement). Reston, VA: Author.

Ostojić, S.M., O'neil, M., Calleja, J., Terrados, N., \& Stojanović, M. (2010). Cardiorespiratory fitness and adiposity in overweight and nonoverweight 8-year-old school children. Minerva Pediatrica, 62(6), 537-343.

Ostojić, S.M., Stojanović, M.D., Stojanović, V., \& Marić, .J. (2010). Adiposity, physical activity and blood lipid profile in 13-year-old adolescents. Journal of Pediatric Endocrinology \& Metabolism, 23(4), 333-343.

Ostojić, S.M., Stojanovic, M.D., Stojanovic, V., Maric, J., \& Njaradi, N. (2011). Correlation between fitness and fatness in 6-14-year old Serbian school children. Journal of health, population, and nutrition, 29(1), 53-56.

Ostojić, S. M., \& Stojanovic, M.D. (2010). High aerobic fitness is associated with lower total and regional adiposity in 12-year-old overweight boys. The Journal of sports medicine and physical fitness, 50(4), 443-449.

Palmer, S., Graham, G., \& Eloise, E. (2005). Effects of a web-based health program on fifth grade children's physical activity knowledge, attitudes and behaviour. American Journal of Health Education, 36, 86-93.

Park, W., Lee, V. J., Ku, B., \& Tanaka, H. (2014). Effect of walking speed and placement position interactions in determining the accuracy of various newer pedometers. Journal of Exercise Science \& Fitness, 12(1), 31-37.

Pate, R. R., Davis, M. G., Robinson, T. N., Stone, E. J., McKenzie, T. L., \& Young, J. C. (2006). Promoting physical activity in children and youth a leadership role for schools: A scientific statement from the American Heart Association Council on Nutrition, Physical Activity, and Metabolism (Physical Activity Committee) in collaboration with the councils on Cardiovascular Disease in the Young and Cardiovascular Nursing. Circulation, (11), 1214-1224.

Physical Activity Guidelines Advisory Committee (2008). Physical Activity Guidelines Advisory Committee Report. Retrived on June 20, 2016, at the World Wide Web: https://health.gov/paguidelines/report/pdf/ CommitteeReport.pdf

Republic Hydrometeorological Service of Serbia. (2015). Mesečni bilten za Srbiju za septembar i novembar 2015. godine (Monthly newsletter for Serbia for September and November 2015). Belgrade: Author. In Serbian

Reynolds, J., Njike, V., Treu, J. A., \& Walker, J. (2010). Putting physical activity where it fits in the school day: Preliminary results of the ABC (Activity Bursts in the Classroom) for fitness program. Preventing Chronic Disease 7(4), 1-10.

Rowe, D. A., Mahar, M. T., Raedeke, T. D., \& Lore, J. (2004). Measuring physical activity in children with pedometers: Reliability, reactivity, and replacement of missing data. Pediatric Exercise Science, 16(4), 343-354.

Ruiz, J. R., Castro-Pinero, J., Artero, E. G., Ortega, F. B., Sjostrom, M., Suni, J., \& Castillo, M.J. (2009). Predictive validity of health-related fitness in youth: a systematic review. British Journal of Sports Medicine. 43(12), 909-923.

Ruiz, J. R., Cavero-Redondo, I., Ortega, F. B., Welk, G. J., Andersen, L. B., \& Martinez-Vizcaino, V. (2016). Cardiorespiratory fitness cut points to avoid cardiovascular disease risk in children and adolescents; what level of fitness should raise a red flag? A systematic review and meta-analysis. British journal of sports medicine, 50(23), 1451-1458.

Sallis, J. F., McKenzie, T. L., Beets, M. W., Beighle, A., \& Erwin, H., \& Lee, S. (2012). Physical education's role in public health: Steps forward and backward over 20 years and HOPE for the future. Research Quarterly for Exercise and Sport, 83(2), 125-135.

Sardinha, L. B., Marques, A., Minderico, C., Palmeira, A., Martins, S., Santos, D. A., \& Ekelund, U. (2016). Longitudinal Relationship between Cardiorespiratory Fitness and Academic Achievement. Medicine \& Science in Sports \& Exercise, 45(5), 839-844.

Scudder, M. R., Lambourne, K., Drollette, E. S., Herrmann, S., Washburn, R., Donnelly, J. E., \& Hillman, C. H. (2014). Aerobic capacity and cognitive control in elementary school-age children. Medicine and Science in Sports and Exercise, 46(5), 1025.

Slaughter, M. H., Lohman, T. G., Boileau, R., Horswill, C. A., Stillman, R. J., Van Loan, M. D., \& Bemben, D. A. (1988). Skinfold equations for estimation of body fatness in children and youth. Human Biology, 709-723.

Smith, J. J., Eather, N., Morgan, P. J., Plotnikoff, R. C., Faigenbaum, A. D., \& Lubans, D. R. (2014). The health benefits of muscular fitness for children and adolescents: a systematic review and meta-analysis. Sports Medicine, 44(9), 1209-1223.

Strong, W. B., Malina, R. M., Blimkie, C. J., Daniels, S. R., Dishman, R. K., Gutin, B., et al. (2005). Evidence based physical activity for school-age youth. The Journal of Pediatrics, 146(6), 732-737.

The Cooper Institute. (2010). Fitnessgram / Activitygram: Test administration manual, 4rd. ed. In: M.D. Meredith, \& G.J. Welk (Eds.). Dallas, TX: The Cooper Institute.

Tudor-Locke, C., Craig, C. L., Beets, M. W., Belton, S., Cardon, G. M., Duncan, S., et al. (2011). How many steps/day are enough? for children an adolescents. International Journal of Behavioral Nutrition and Physical Activity, 8, 78 . 
Walther, C., Gaede, L., Adams, V., Gelbrich, G., Leichtle, A., Erbs, S., et al. (2009). Effect of increased exercise in school children on physical fitness and endothelial progenitor cells a prospective randomized trial. Circulation, $120(22), 2251-2259$.

Weineck, J. (2007). Endurance training. In: S. Medizin (Ed.), Optimal training, 16th ed. (pp. 156-261). Balingen, Germany: Spitta Verlag GmbH \& Co. KG.

World Health Organization-WHO (2004). Global strategy on diet, physical activity and health. Geneva: Author.

Zahner, L., Puder, J.J., Roth, R., Schmid, M., Guldimann., Puhse, U., et al. (2006). A school-based physical activity program to improve health and fitness in children aged 6-13 years ("Kinder-Sportstudie KISS"): study design of a randomized controlled trial [ISRCTN15360785]. BMC Public Health, 6-147.

\section{EFEKTI FITT PROGRAMA NA FIZIČKU AKTIVNOST I FIZIČKU FORMU POVEZANU SA ZDRAVLJEM DECE MLAĐEG ŠKOLSKOG UZRASTA}

Cilj istraživanja je evaluacija efekata osmonedeljnog FITT programa fizičkog vaspitanja na fizičku aktivnost (FA) i fizičku formu povezanu sa zdravljem (FFPZ). U eksperimentalnoj grupi (N=92) su putem FITT smernica učenici ,uvođeni“ u zonu razvoja FFPZ. Realizovano je 16 časova za razvoj aerobne forme i 8 časova za razvoj mišićne forme. Fleksibilnost je razvijana u završnom delu svakog $\check{c}$ asa. Konrolna grupa $(N=86)$ je pohađala tradicionalne časove istog obima. Pre i nakon intervencije vršena je procena FFPZ baterijom testova FITNESSGRAM i FA pedometrom OMRON HJ-320. U obe grupe je došlo do značajnog povećanja u maksimalnoj potrošnji kiseonika i broju istrčanih deonica (PACER laps), uz istovremen pad nivoa FA. FITT program je značajno više doprineo unapređenju aerobne forme, mišićne forme i delimično fleksibilnosti. Nisu se ispoljile razlike između grupa u telesnom sastavu i nivou FA. FITT inervencija je obećavajuća školska strategija za poboljšanje aerobne i mišićne forme učenika.

Ključne reči: školska intervencija, osnovna škola, treći razred 